\title{
MORE ABOUT THE DETERMINATION OF DEATH BY NEUROLOGIC CRITERIA
}

\author{
Author: $\quad$ Calixto Machado \\ Institute of Neurology and Neurosurgery, Havana, Cuba
Address: Calixto Machado, MD, Ph.D., FAAN (Corresponding Author)
Institute of Neurology and Neurosurgery
Department of Clinical Neurophysiology
29 y D, Vedado
La Habana 10400
Cuba
Email: braind@infomed.sld.cu

\section{Author's Highlights:}

Dr. Calixto Machado graduated as MD in 1976. He continued his medical training to become Specialist in Neurology and Clinical Neurophysiology, First Degree in 1980, and Second Degree in 1984. In 1990 he became the youngest Dr. in Sciences in his country. Dr. Machado received clinical training in specialized neurology centers in Sweden, Italy, Austria, and USA

In 1992, he was the first Cuban neurologist who was a member of the American Academy of Neurology (AAN), nominated as a Corresponding Fellow. He has been awarded 15 times by the Best Annual Scientific Medical Research in Cuba. In 2005 he received the American Academy of Neurology "Lawrence McHenry Award", and in 2011, he was awarded as the "Researcher of Year" by the International Academy for Child Brain Development (Philadelphia, USA), and by the International Association of Functional Neurology and Rehabilitation (Orlando, USA). These were the first time that a Hispanic neurologist, and a neuroscientist from a developing country, received those recognitions.

$\mathrm{He}$ is Senior Professor and Researcher at the Institute of Neurology and Neurosurgery, Havana, Cuba. He is actually the President of the Cuban Society of Clinical Neurophysiology and of the National Commission for the Determination of and Certification of Death.

$\mathrm{He}$ has been the President of the Organizing Committee of the International Symposia on Brain Death and Disorders of Consciousness, since the 90's (8 symposia). These conferences have gathered hundreds of foreign delegates from the whole globe.

During the last 30 years he has run many research protocols on subjects, such as: brain death, coma, persistent vegetative states and other disorders of consciousness, stroke, autism, etc. He has published more than 400 peer reviewed articles, book chapters, and 4 books. His Book "Brain Death: A Reappraisal" was received with great enthusiasm among neurologist, neurosurgeons, intensivists, and surgeons specialized in transplants. He is considered one of the most productive investigators in the area of brain death and disorders of consciousness. 
Lewis et al. published an important and timely necessary article about the determination of death by neurological criteria, revising the Uniform Determination of Death. ${ }^{1}$

The acceptance of brain death (BD) has been progressively accepted beginning at the late 1950 s. ${ }^{2-13}$ Nonetheless, contentious brain-death cases have recently raised new controversies about the diagnosis of $\mathrm{BD}$, such as the Jahi McMath case, extensively covered by the US and international press. ${ }^{14-24}$. Jahi McMath meant a terrible tragedy for her and her family. But further than this gloomy story, the case has also raised confusion and challenging qualms about a fundamental query: how we confirm whether a person is dead or alive ${ }^{20,23,25-28}$

Since 1981, the Uniform Determination of Death Act (UDDA) has served as the legal foundation for the medical practice of determining death. ${ }^{29,} 30$ But, although death by neurologic criteria is considered legal death throughout the United States, several recent lawsuits have quizzed the rightfulness the authority of the UDDA to declare death by neurological criteria. ${ }^{18,31-36}$ This issue explains the importance of Lewis's et al. paper. ${ }^{1}$

In this article I want to present the historical procedure for issuing a law in Cuba for the determination and certification of death. ${ }^{20,24,37-43}$ Of course, it is impossible to compare our country with USA. Cuba is a small and developing country, in which a law encompasses a national scenery, in contrast with USA, a multistate nation. 


\section{Cuban Law for the Determination of Death}

The Civil Code

The Cuban Civil Code has undergone several historical changes regarding the determination of death. $24,25,40,42,44$

The Spanish Civil Code, established in Cuba since 1889, stated in Article 31:

"Death occurs when the person is extinguished."

The subsequent Civil Code (Cuban Law 1175, March 9, 1965) stated ${ }^{40}$ :

"Death is the loss of every sign of life after a living birth."

The development of Article 26.1 of the present Civil Code (July 1987) ${ }^{25}$ stated:

"Physicians are the only professionals authorized to diagnose and certify

death according to a norm established by the Ministry of Public Health."

Distinguishing Features of Article 26.1 of the Current Cuban Civil Code)24, 25, 41-

43

- It does not define death.

- It specifies that physicians are the only professionals authorized to diagnose and certify death.

- It specifies that the Ministry of Public Health must provide a norm for the determination of death (clinical and instrumental criteria).

- The Cuban Parliament gave full responsibility to the 
Ministry of Public Health to legalize the determination and certification of death.

\section{Law Within a Ministry}

According to the Cuban Parliament, a resolution is a law that legalizes a working standard within any ministry and that could be signed and changed by the minister in function. Therefore, the Ministry of Public Health needed to respond to the present Civil Code, Article 26.1, by writing a resolution on this subject. ${ }^{25}$

For this reason, the Ministry of Public Health organized the National Commission for the Determination and Certification of Death at the beginning of the 1990's. Since that date I was nominated as the President of the Commission, and it was finally composed with representatives from multiple disciplines, including various medical and legal specialties. After several versions, the Commission wrote the final resolution, signed by the Minister of Public Health on August 27, 2001 (Fig 1). ${ }^{43}$

The main body of the norm contained the following points: ${ }^{40,43}$ :

- Physicians diagnose death by documenting the "signs of death."

- When the diagnosis of death is based on the irreversible loss of whole brain functions, medical specialists need to be accredited by the National Commission for the Determination and Certification of Death.

- Death is certified by the physician who diagnoses it. Physicians will register the moment of death upon completing the diagnostic procedure. 
- The commission will annually review the diagnostic criteria of death and will propose changes or amendments, according to medical and technological advances in this area.

\section{GACETA ${ }^{\oplus}$ FICIAL \\ DE LA REPUBLICA de CUBA \\ MINISTERIO DE JUSTICIA \\ EDICION ORDINARIA LA HABANA, YIERNES 21 DE SEPTIEMBRE DEL: 2001 ANO XCIX \\ SALUD PU'BLICA' RESOLUCION MINISTERIAL Nং 90}

Figure 1. Cuban law for the determination and certification of death.

Diagnosis of Death

The National Commission accepted only one kind of death $39,40,45$ :

The irreversible loss of whole brain functions, including the brainstem and the cerebral hemispheres.

The Commission also recommended to consider my new definition of death, based on the patho-physiological mechanism for generation of consciousness: ${ }^{46-48}$ Irreversible loss of the consciousness which provides the key human attributes and the highest level of control in the hierarchy of integrating functions within the human organism. 
This definition has as an anatomical and functional substratum:

Irreversible destruction of the anatomic and functional substratum for the generation of both components of consciousness (arousal and awareness) throughout the whole brain.

Although the Commission accepted that there is only kind of death (the irreversible loss of whole brain functions, including the brainstem and the cerebral hemispheres), also emphasized that there are several ways of diagnosing it, according to the place and environment where death occurs. ${ }^{40,}$ 43

1. Outside the intensive care environment (no ventilatory and cardiocirculatory support), where physicians apply the cardio-circulatory and respiratory criteria.

2. In forensic medicine circumstances physicians assess cadaveric signs. (They do not even need a stethoscope.)

3. In the intensive care environment (no ventilatory and cardiocirculatory support), when cardio-circulatory and/or respiratory arrest occurs physicians utilize the cardio-circulatory and respiratory criteria. When physicians suspect an irreversible loss of brain functions in heart-beating and ventilatory supported cases, BD diagnostic criteria are applied. 
Signs of Death:

I- Irreversible loss of respiratory function.

II- Irreversible loss of cardio-circulatory functions.

III- Algor mortis (postmortem coldness).

IV- Livor mortis (postmortem lividity).

V- Rigor mortis (postmortem rigidity).

VI- Cadaveric spasm.

VII- Loss of muscle contractions.

VIII- Putrefaction.

IX-BD diagnosis.

The commission adopted the view that the irreversible loss of cardiocirculatory and respiratory functions can only cause death when ischemia and anoxia are prolonged enough to produce an irreversible los of functions of the whole brain. ${ }^{40 \text {, }}$ 49-51

Physicians diagnose death by finding the "signs of death." Signs I and II correspond to the classic respiratory and cardiocirculatory functions, which can be applied in scenarios without an intensive care setting. Signs III to VIII are related to forensic circumstances. Sign IX corresponds to BD diagnosis

The description of the way to assess the signs of death, including BD diagnosis, according to our Commission is outside the scope of this article, and can be found elsewhere. . ${ }^{38,40,49-52}$

The Commission also stated that any legal code of death should be completely separate from any norm governing organ transplants. In fact, in our legal norm, the word "transplant" is not cited. ${ }^{43,53}$ 


\section{Final remarks}

Lewis et al. ${ }^{1}$ also clearly discussed the question about pituitary/hypothalamic function preservation in suspected brain-dead cases. ${ }^{54,55}$ In the case of Jahi McMath, the family's legal position assured that she was alive because in large part on continued hormonal function manifested by menstruation. ${ }^{18,21-23}$ On the contrary, I assured that Jahi McMath was not braindead, because ancillary tests performed 9 months after initial brain insult, showed conservation of intracranial structures, EEG activity, and autonomic reactivity to "Mother Talks" stimulus. I concluded that Jahi McMath represented a new state of disorder of consciousness, non-previously described, that I have termed: "responsive unawake syndrome" (RUS). ${ }^{20,24,56}$ Nonetheless, the preservation of hormonal function in BD deserves further attention. ${ }^{57-59}$

It is necessary to finally remark that, although there is only one kind of human death, based on the irreversible loss of functions of the whole brain, there are several ways of diagnosing death, according to the scenario where death occurs. Nonetheless, it does not mean that there are different kinds of deaths. ${ }^{20,24,40,60-63}$

\section{REFERENCES}

1. Lewis A, Bonnie RJ, Pope T, et al. Determination of Death by Neurologic Criteria in the United States: The Case for Revising the Uniform Determination of Death Act. J Law Med Ethics 2019;47:9-24.

2. $\mathrm{P} M, M$ G. Coma dépassé (preliminary memoir). Rev Neurol (Paris) 1959;101:3-15. 
3. Walker AE, Diamond EL, Moseley J. The neuropathological findings in irreversible coma. A critque of the "respirator". J Neuropathol Exp Neurol 1975;34:295-323.

4. Bernat JL. A Conceptual Justification for Brain Death. Hastings Cent Rep 2018;48 Suppl 4:S19-S21.

5. Bernat JL. Whither brain death? Am J Bioeth 2014;14:3-8.

6. Bernat JL. Death by neurologic criteria 1968-2014: changing interpretations. Forward. J Crit Care 2014;29:671-672.

7. Bernat JL. The definition and criterion of death. Handb Clin Neurol 2013;118:419-435.

8. Bernat JL. Brain death. Occurs only with destruction of the cerebral hemispheres and the brain stem. Arch Neurol 1992;49:569-570.

9. Machado C. Further thoughts about the "transatlantic divide" in brain death determination.

Anaethesia 2019;74:http://www.respond2articles.com/ANA/forums/thread/2778.asp.

10. Machado C. Reader response: Brain death, the determination of brain death, and member guidance for brain death accommodation requests: AAN position statement. Neurology 2019;93:946-947.

11. C. M. A new definition of death based on the basic mechanisms of consciousness generation in human beings. In: C M, ed. Brain Death (Proceedings of the Second International Symposium on Brain Death). Amsterdam: Elsevier Science, BV, 1995: 57-66.

12. Wijdicks EFM. How Harvard Defined Irreversible Coma. Neurocrit Care 2018;29:136-141. 
13. Wijdicks EF. Brain death. Handb Clin Neurol 2013;118:191-203.

14. Walter U, Brandt SA. [Diagnosis of irreversible loss of brain function ("brain death")-what is new?]. Nervenarzt 2019;90:1021-1030.

15. Pope T. Brain Death and the Law: Hard Cases and Legal Challenges. Hastings Cent Rep 2018;48 Suppl 4:S46-S48.

16. Goodwin M. Revisiting Death: Implicit Bias and the Case of Jahi McMath. Hastings Cent Rep 2018;48 Suppl 4:S77-S80.

17. Lewis A. The Legacy of Jahi McMath. Neurocrit Care 2018;29:519-520.

18. Lewis A. Reconciling the Case of Jahi McMath. Neurocrit Care 2018;29:2022.

19. Lewis A. Response to Machado et al. re: Jahi McMath. Neurocrit Care 2018;29:523-524.

20. Machado C, Estevez M, DeFina PA, Leisman G. Response to Lewis A: Reconciling the Case of Jahi Mcmath. Neurocrit Care 2018;29:521-522.

21. Shewmon DA. The Case of Jahi McMath: A Neurologist's View. Hastings Cent Rep 2018;48 Suppl 4:S74-S76.

22. Shewmon DA. Truly Reconciling the Case of Jahi McMath. Neurocrit Care 2018;29:165-170.

23. Truog RD. Lessons from the Case of Jahi McMath. Hastings Cent Rep 2018;48 Suppl 4:S70-S73.

24. Machado C. Reader response: Variability in reported physician practices for brain death determination. Neurology 2020;94:97.

25. Ley No. 59 del 16 de Julio de 1987 (Código Civil). La Habana, Cuba: Ministerio de Justicia. Gaceta Oficial de la Republica de Cuba. Edicion 
Extraordinaria no. 9. , 1987: 39-81.

26. Truog RD, Berlinger N, Zacharias RL, Solomon MZ. Brain Death at Fifty: Exploring Consensus, Controversy, and Contexts. Hastings Cent Rep 2018;48 Suppl 4:S2-S5.

27. Truog RD, Pope TM, Jones DS. The 50-Year Legacy of the Harvard Report on Brain Death. JAMA 2018;320:335-336.

28. Truog RD. Defining Death-Making Sense of the Case of Jahi McMath. JAMA 2018;319:1859-1860.

29. Determination of death (Uniform Determination of Death Act of 1981); natural death (Natural Death Act of 1981).LEXIS District of Columbia code1981.

30. President's Commission for the Study of Ethical Problems in Medicine and Behavioural Research:Defining Death. Medical Legal and Ethical Issues

in the Determination of Death. Washington DC: U.S. Government Printing Office, 1981.

31. McGee A, Gardiner D. Differences in the definition of brain death and their legal impact on intensive care practice. Anaesthesia 2019.

32. Cartolovni A, Habek D. Guidelines for the management of the social and ethical challenges in brain death during pregnancy. Int J Gynaecol Obstet 2019;146:149-156.

33. Yanke G, Rady MY, Verheijde JL. Ethical and Legal Concerns With Nevada's Brain Death Amendments. J Bioeth Inq 2018;15:193-198.

34. Lewis A, Greer D. Medicolegal Complications of Apnoea Testing for Determination of Brain Death. J Bioeth Inq 2018;15:417-428.

35. Lewis A, Greer D. Current controversies in brain death determination. Nat 
Rev Neurol 2017;13:505-509.

36. Pope TM, Okninski ME. Legal Standards for Brain Death and Undue Influence in Euthanasia Laws. J Bioeth Inq 2016;13:173-178.

37. Machado C, Estevez M, DeFina PA, Leisman G. Reader response: An interdisciplinary response to contemporary concerns about brain death determination. Neurology 2018;91:535.

38. Machado C. Diagnosis of brain death. Neurol Int 2010;2:e2.

39. Machado C. Describing life to define death: a Cuban perspective. MEDICC Rev 2010;12:40.

40. Machado C. Brain Death: A reappraisal. New York: Spinger Science+Bussiness Media, LLC, 2007.

41. Machado C. Determination of death. Acta Anaesthesiol Scand 2005;49:592593.

42. Machado $\mathrm{C}$, Abeledo M, Alvarez $\mathrm{C}$, et al. Cuba has passed a law for the determination and certification of death. Adv Exp Med Biol 2004;550:139-142.

43. Machado C. [Resolution for the determination and certification of death in Cuba]. Rev Neurol 2003;36:763-770.

44. Machado C. A definition of human death should not be related to organ transplants. J Med Ethics 2003;29:201-202.

45. Machado-Curbelo C. [Do we defend a brain oriented view of death?]. Rev Neurol 2002;35:387-396.

46. Machado C. Death on neurological grounds. J Neurosurg Sci 1994;38:209222.

47. Machado C. Consciousness as a definition of death: its appeal and 
complexity. Clin Electroencephalogr 1999;30:156-164.

48. Machado $\mathrm{C}$. Is the concept of brain death secure? . In: Zeman AE, L. , ed. Ethical Dilemmas in Neurology. London: W. B. Saunders Company, 2000: 192-213.

49. Machado C, Korein J. Irreversibility: cardiac death versus brain death. Rev Neurosci 2009;20:199-202.

50. Machado-Curbelo C. [A new formulation of death: definition, criteria and diagnostic tests]. Rev Neurol 1998;26:1040-1047.

51. Machado C. Death on neurological grounds. J Neurosurg Sci 1994;38:209222.

52. Machado C, Perez-Nellar J, Estevez M, Gonzalez E. Evidence-based guideline update: Determining brain death in adults: report of the Quality Standards Subcommittee of the American Academy of Neurology. Neurology 2011;76:307; author reply 308-309.

53. Machado C, Kerein J, Ferrer Y, Portela L, de la CG, Manero JM. The concept of brain death did not evolve to benefit organ transplants. J Med Ethics 2007;33:197-200.

54. Nair-Collins M, Northrup J, Olcese J. Hypothalamic-Pituitary Function in Brain Death: A Review. J Intensive Care Med 2014.

55. Lopau K, Mark J, Schramm L, Heidbreder E, Wanner C. Hormonal changes in brain death and immune activation in the donor. Transpl Int 2000;13 Suppl $1: S 282-S 285$.

56. Machado CD, P.A.; Estevez, M.; Leisman, G.; Rodriguez, R.; Presitigiacomo, C.; Fellus, J.; Halper, J.; Chinchilla, M.; Aubert, E.; Machado, Y.; Machado, 
Y. A Reason for care in the clinical evaluation of function on the spectrum of consciousness Journal Functional Neurology, Rehabilitation and Ergonomics and Rehabilitation 2017;4:542-556.

57. Nair-Collins M, Northrup J, Olcese J. Hypothalamic-Pituitary Function in Brain Death: A Review. J Intensive Care Med 2016;31:41-50.

58. Vespa PM. Hormonal dysfunction in neurocritical patients. Curr Opin Crit Care 2013;19:107-112.

59. Chen EP, Bittner HB, Kendall SW, Van TP. Hormonal and hemodynamic changes in a validated animal model of brain death. Crit Care Med 1996;24:1352-1359.

60. Machado C, Estevez M. Reader Response: Practice Current: When do you order ancillary tests to determine brain death? Neurol Clin Pract 2018;8:364.

61. Machado C. Historical evolution of the brain death concept: additional remarks. J Crit Care 2014;29:867.

62. Machado C. Death as a biological notion. J Crit Care 2014;29:1119-1120.

63. Machado C, Estevez M, Rodriguez $\mathrm{R}$, et al. A Cuban perspective on management of persistent vegetative state. MEDICC Rev 2012;14:44-48. 